\title{
Colloquy
}

\section{UNDERGROUND INSCRIPTIONS}

\author{
MICHELE LANCIONE \\ University of Sheffield \\ (D) http:/ / orcid.org/0000-0002-9018-3562
}

One day in fall 2003, Radu asked me if I was interested in seeing his place. We were standing in front of an open manhole, with a provisional iron ladder descending into the darkness below. Grozăvești metro station lay a few meters away, while Bucharest gloomed all around, crisscrossed by poorly maintained infrastructure, failing pipes, frozen sidewalks, and a frenzy of billboards proclaiming the advantages of belonging to the "common family" of the European Union (EU). Glimpsing the dark end of the ladder I was both terrified and intrigued. I had known Radu a few months, seeing and chatting with him every day on my way to and from the university. Although we were just a few years apart in age, we did not have much in common: he was one of the many copii străzi living on the streets, ${ }^{1}$ I was an Erasmus student; he was pumping a synthetic colorant (Aurolac) from a plastic bag, while I did not even smoke; he had a past marked by a history of violence and institutionalization, while I was a working-class kid who had never experienced such life conditions. Yet we chatted every day, ate merdenele cu brânză sărată together, and grew to trust each other. So I accepted his invitation.

He moved down first and I tentatively followed, finding myself at the bottom of the ladder, staring into the darkness, without a clue what was going to happen. 
My senses were overwhelmed by the pitch-black hole, the humidity, the heat, the reek of piss and melted garbage. My glasses fogged, my face misted, my whole body shook. Some moments of suspension: in between life, aboveground and below; in between homing and uninhabitability. Then light came in the form of a candle held by a young boy. Things were still mushy, but they gradually began to acquire clarity. The contours of a huge pipe running along one of the walls emerged from the dark. On the ground: rubbish, mattresses, covers - food leftovers, stagnating water - a cap, a jumper. Right in the middle of this scene: Radu and his younger friend looking at me-their eyes in suspension_-waiting, perhaps, for a comment, an articulation of some sort. This was not what I was expecting, yet there it was - what he called home.

Bucharest has changed considerably in the fifteen years following this encounter. The colonizing discourse that depicts eastern Europe as the other of "real" western Europe was boosted by the so-called transition of former socialist countries to capitalism (Hall 1992; Popovici and Pop 2016). From the early 1990s onward, the cultural doxa ran that the country must be "modernized," rejecting everything associated with its recent past. The ruling classes, within the EU and other international bodies, translated this into the massive privatization and then financialization of housing, industry, and public space (Chelcea and Druţǎ 2016; Deoancă 2017; Vincze 2017). Many have felt and lived the consequences. For homeless people and drug users like Radu, but also for sex workers, the elderly poor, racialized others, and many more, the past thirty years have intensified a long history of exploitation, racialization, and neglect (Lancione 2019a; McElroy 2019).

In between the cracks of these historical makings, communities of bucureștean have continued to live in underground tunnels crisscrossed by pipes running hot waters (part of the city's massive tele-heating system); in abandoned shopping malls; in blocks already marked for demolition by the previous regime; in patchworked shacks located on public pavements or alongside railway lines; and within similar forms of supposed uninhabitability (Simone 2018). Yet there is more to these lives and stories than what the sociology of resilience, capability, and humanitarianism might suggest. As Angela Garcia (2010) shows in her work with addicts in New Mexico's Española Valley, the continuation and (re)affirmation of these margins is neither a matter of bare survival nor one of resilience. It is not that the bodies here fell through the cracks of history and are now waiting for a Godot-like something to happen, nor are they in need of celebrations for their endurance. Such a colonizing discourse does not capture the reverberations emerging from the cracks, the light coming through, as Gloria E. Anzaldúa (2015) puts it; instead it 
silences them by reappropriating their uncanny propositions within its normalizing governmentalities (Foucault 2016).

By contrast, an approach inspired by decolonial and radical feminist politics sees the uninhabitable of Bucharest as places from which an affective proposition emerges that concerns more than survival, a statement about a form of life and a mode of becoming. This is about seeing the margins not only as a site of neglect but also as an active site of resistance: an affirmation of life despite its impossibilities (hooks 1990). Crucially, this constitutes an affirmation that does not intend to fit within the dominant narrative, since it is precisely that violent and racialized narrative that has annihilated it from the start (Roy 2019). Life at the margins of Bucharest, in its underground tunnels, takes its own form, its own weird assemblage: it is a life that saves itself from its own history, one that refuses institutionalization, and one that constructs its own way of being into the world - that is, its own way of dwelling, by caring for its own unfolding (Lancione 2019b).

$$
* * *
$$

In 2014 I saw Radu again, this time in a different tunnel passing under the main train station of Bucharest. Our encounter was possible thanks to a photograph I had taken of him in 2003: a friend recognized Radu, and brought me to the Gara de Nord tunnel. When I meet him, Radu doesn't remember me, but he recognizes himself in the old picture. He is surprised, and I am too: Radu has been living underground for more than eleven years, in warm tunnels filled with syringes running through the belly of the city. In there he feels, as he and the community put it, acasa, at home. Day after day, he and other members of the community show me around their home. The tunnels become known to me as a fluid assemblage of pipes and veins, an interlace forming a living infrastructure making life possible underground (Amin 2014). In a vitalist sense, this infrastructure can be seen as that shared plane where the economy of being at home was gathered in injecting heroine and mephedrone, but also in constructing collective assemblages of care by sharing food; by shouting at each other; by watching TV; by exchanging water, doses, and money; by climbing above ground to reconnect the tunnel's electricity cable to the public lamp; by buying petrol for the electric generator; by scavenging copper wires and other scrap materials from the city's trash bins, bringing them down, arranging them according to value and use, and bringing them out again for sale to recyclers; and by many other everyday matters, all taking place within and with a tunnel planned for energy efficiency and collective consumption by the Republica Socialistă România decades ago (see Lancione 2019c). 
The economy of care that all these arrangements brought to the fore made life in the underground possible, allowing inhabitants (as they put it) to become autonom din afară, independent from the outside, to create a home that offered an alternative to the supposed solutions provided by the city (homeless shelters, rehabs, jails). Crucially, however, the economy of care in the underground does not leave evident traces: it is labile, ephemeral, largely hidden from sight, and when its traces are brought to light, they tend to be subsumed and categorized as deviant, pathological, in need of reparation. What I argue in my work is that only in paying attention to the nuanced makings of life at the margins - only in following the unfolding of its (under)grounded becoming — can one retrieve its politics of care and understand it for what it is: a proposition of its own standing, an underground inscription impossible to appropriate and sustainable only in its own refrains, at its own tempo (Guattari 2009).

The following encounter describes Radu helping a friend, Andra, to inject legale - a powdered mix with mephedrone at its core. I am reporting it here to open a window on the ways in which care in the underground was brought to the fore, in the midst of extreme poverty, addiction, and diseases - but also within a shared sense of community, independence, and self-sustenance. The limited space of this essay does not allow me to give justice to the extensive complexity of these makings, which are an effect of historic lineages but also the producer of alternative ways of lives. Yet the following passage hopefully provides a hint about the collective endeavor brought to the fore to align the conditions making life possible in the underground. This is a form of collective caring labor, a maker of home and belonging, inscribed also in the excruciating act of injection (Garcia 2010).

Andra is sitting on one pipe, I am sitting close to her. All around us, there are people sleeping, talking, standing, passing by.

Andra: [speaking toward Radu] Come, will you inject me?

He nods and stands in front of her, in the middle of the narrow corridor between the pipes. A gap no larger than two hands means people have to squeeze past. Andra and Radu do not speak. He gets the dose from her and prepares it. Once it is ready, he tries to inject her, but finding a vein is difficult. He tries three or four times on her arms, then Andra pulls her sweatshirt up, and he tries again on her side. 
Andra: I'm not bleeding properly.

Me: Yeah?

Radu keeps trying to inject her. Inside the tunnel it is very hot and he is sweating. Andra is visibly tense. All around, people shout at each other to obtain syringes or to buy stuff. In the background, a manele pop song plays loudly from the community's TV set.

Radu: She's also nervous, right? Take her hand.

Radu keeps on trying to inject Andra in different places. He inserts the needle in her arms, then her hands, trying to pull some blood into the barrel. All around noises and movements continue, but the two are concentrating on their task. They do not talk.

Andra: Wait, ho! [Andra shouts at someone passing right below Radu, making him move while the syringe is planted in her skin.]

Me: [to Radu] It's very hard, right?

Radu: Due to burned veins. She injected too much in the veins.

Andra: Here! [Andra points at a place on her side.]

Radu tries to inject there.

Radu: There's no blood entering the rig, haven't you seen it? The syringe hardly gets through the vein because it's too stiff.

Radu tries again. At this point, Andra has been jabbed by the syringe at least a dozen times.

Andra: $O K$, it's in.

Radu tries to pull some blood, and it seems to work. He pushes the pump and, very tentatively, the substance enters Andra's body. 
Andra: Finally, it's in!

Radu slowly pulls the needle out and throws the syringe away.

Andra: That's it, it's in . . . [She says something inaudible to Radu.]

Radu: Leave me alone, it didn't work how you told me, look how much I have had to wait [referring to the fact that he tried to inject in many places, under Andra's direction]. You've embarrassed me, look!

Andra: Yeah. I was so scared...2

Collective resources — bodily, affective, relational, and material — needed to be aligned for Andra to receive her shot. The outcome was not entirely dependent on her own will, nor that of Radu. Yet Andra knew that she could not have done it alone and had to entrust someone else with her skin, her body, and her own addiction. Yet Andra and Radu's exchange signals more than a favor between two friends. It also constituted a form of caring for the other — of being concerned for one's else position - that needs to be grounded in its historic and present makings. Through it, one can see traces of a habitual form of being together, of sharing the same space without having to fight for it, of feeling secure in the midst of dozen of bodies crumpled in a tiny underground corridor, of looking for the same substances and sharing the same needs. This was about sitting within the same common home, crafted around the community's wish to live independently and united, despite what the normalizing city aboveground thought of or made of it. The complexity of these forms of "caring otherwise," to follow the term used by Lauren Cubellis and Rebecca Lester (forthcoming), is frightening, because to see its traces one has to step away from the mainstream moralities and dig into the uncomfortable cosmos of their makings (Stengers 2005). Yet in allowing for that displacement to happen, impossible homes might come to the fore and weird propositions about the acceptability and possibility of life might emerge, taking the form of a shared solidarity that is political even if doesn't shout about its politics in the canonical ways (Simone 2018).

But even if one is ready to allow for that displacement, and to accept that "one can live a life of dignity and integrity in the midst of poverty" (hooks 1994, 199) according to its own makings, of certain things, like Andra's veins, almost no traces exist. They are hard to see, to let emerge, and to hear speak. Even more so 
when their extended collective life, attached and sustained by the entire mechanosphere of the tunnel and its pipes, is silenced in its violent exposition to the world aboveground. This is what happened in June 2015, when the local authorities decided to evict the community of Gara de Nord, following a media storm generated by a number of international TV reports about life in the tunnels. ${ }^{3}$ Some of the inhabitants were arrested, others displaced, and the entrances to the tunnels were sealed. According to conversations I had with one of the few providers of harm-reduction services for drug users in the city, many community members could not sustain themselves outside of the tunnel, and eventually died. What was lost in the eviction was not simply shelter but also a caring economy made of affective and material connections that went well beyond its depiction by the city aboveground.

But if one sees the light emerging from the cracks, if one registers the weird politics of care inscribed within the margins, something powerful still remains of those lives and stories. These are inscriptions, ways of being together and becoming, that Bucharest's underground communities carved throughout the belly of the city and through their displaced histories. I understand them as affections and orientations that lie beyond, below, and within traces: they are matters, to paraphrase Lisa Stevenson (2014), that have a life beside themselves. Resistant to light and to immediate appropriation, they become visible only if one sees their own markings, their own way of tracing life on earth. In their being in between evident traces and outright ghosts, they reveal with their translucence how life at the margins is possible on its own terms, speaking the proposition of the uninhabitable in its own grammar, at its own tempo (Lancione 2019c). If tracing is about retrieval, inscription requires a more nuanced hermeneutic approach, one attentive to the complex making of weird assemblages and their politics. It is only when the assemblage of the underground is let to unfold and to speak its proposition that one can see why and how Radu is caring for Andra, and how home can be possible in the uninhabitable (Simone 2018).

Registering what these inscriptions have to say through their affective and material being in the world constitutes the prerequisite for writing a radical political history of life at the margins in Bucharest, and possibly beyond. Such an endeavor contains, within itself, an invitation to slow things down and listen, and to be attentive to a politics of endurance that comes through the margins and needs only to be sustained (through appropriate harm-reduction interventions) rather than being "solved," or subsumed into the many. The boschetari of Gara de Nord never saw themselves as homeless, so the homeless shelter provided by the city never appealed to them as a solution. Radu and his peers inscribed their own way 
into the city from below, cutting across a long-standing history of neglect and deprivation. What that inscription reads and proposes is a life sustained by a politics of care that exceeded everything the city has offered, and could ever offer, them.

\section{ABSTRACT}

This essay examines the politics of home in underground Bucharest, and the ways relationships of care among homeless drug users emerge amid everyday violence and exclusion, illuminating the unconventional practices of belonging that take shape in transient communal spaces such as underground electric, transportation, and waste-management systems. The traces of systemic exclusion in these experiences converge in makeshift forms of kinship and care, provoking questions of solidarity, fragility, and the political potential of recognizing such forms through ethnographic collaboration. [homelessness; kinship; substance use]

\section{NOTES}

Acknowledgments The author wishes to thank his comrades of the Common Front for the Right to Housing (FCDL) and the NGO Carusel in Bucharest; Lauren Cubellis and Rebecca Lester for the invitation to this dialogue; and the Cultural Anthropology editorial team for their care and dedication.

1. Inspired by the work of Gloria E. Anzaldúa (2015), in my writing I retain influences of the languages I speak and think with - including Romanian and Italian. This might require a level of additional effort from the reader, but it reflects the conditions of knowledge production through which a piece like this one was written.

2. This whole episode lasted around ten minutes. The conversation was audio-recorded with the explicit agreement of Andra and Radu. Translated from Romanian by Dr. Alina Huzui-Stoiculescu and checked by the author.

3. Including an award-winning short report by the UK Channel 4, and more from Al-Jazeera, Deutsche Welle, ABC, and others, all available online.

\section{REFERENCES}

Amin, Ash

2014 "Lively Infrastructure." Theory, Culture and Society 31, nos. 7-8: 137-61. https:// doi.org/10.1177\%2F0263276414548490.

Anzaldúa, Gloria E.

2015 Light in the Dark / Luz en lo oscuro: Rewriting Identity, Spirituality, Reality. Edited by Analouise Keating. Durham, N.C.: Duke University Press.

Chelcea, Liviu, and Oana Druță

2016 "Zombie Socialism and the Rise of Neoliberalism in Post-socialist Central and Eastern Europe." Eurasian Goegraphy and Economics 57, nos. 4-5: 521-44. https:// doi.org/10.1080/15387216.2016.1266273.

Cubellis, Lauren, and Rebecca Lester, eds.

Forthcoming Traces of Care: Discernment and the Work of Recognition. Durham, N.C.: Duke University Press. 
Deoancă, Adrian

2017 “Class Politics and Romania's 'White Revolution.”'Anthropology News 58, no. 4: Foucault, Michel e394-e398. https://doi.org/10.1111/AN.502.

2016 Abnormal: Lectures at the College de France 1974-1975. Edited by Valerio Marchetti Garcia, Angela and Antonella Salomoni. Translated by Graham Burchell. London: Verso.

2010 The Pastoral Clinic: Addiction and Dispossession along the Rio Grande. Los Angeles: University of California Press.

Guattari, Félix

2009 Soft Subversions: Texts and Interviews 1977-1985. Los Angeles: Semiotext(e).

Hall, Stuart

1992 "The West and the Rest: Discourse and Power." In Formations of Modernity, edited

hooks, bell by Stuart Hall and Bram Gieben, 275-332. London: Polity.

1990 "Marginality as a Site of Resistance." In Out There: Marginalization and Contemporary Culture, edited by Russell Ferguson, Martha Gever, Trin T. Minh-ha, and Cornel West, 341-44. Cambridge, Mass.: MIT Press.

1994 Outlaw Culture: Resisting Representations. New York: Routledge.

Lancione, Michele

2019a "The Politics of Embodied Urban Precarity: Roma People and the Fight for Housing in Bucharest, Romania." Geoforum 101: 182-91. https://doi.org/10.1016/j. geoforum.2018.09.008.

2019b "Radical Housing: On the Politics of Dwelling as Difference." International Journal of Housing Policy. https://doi.org/10.1080/19491247.2019.1611121.

2019c "Weird Exoskeletons: Propositional Politics and the Making of Home in Underground Bucharest." International Journal of Urban and Regional Research 43, no. 3: 535-50. https://doi.org/10.1111/1468-2427.12787.

McElroy, Erin

2019 "Digital Nomads in Siliconising Cluj: Material and Allegorical Double Dispossession.” Urban Studies. https://doi.org/10.1177/0042098019847448.

Popovici, Veda, and Ovidiu Pop

2016 "From Over Here, in the Periphery: A Decolonial Method for Romanian Cultural and Political Discourses." LeftEast, February 11. https://www.criticatac.ro/ lefteast/from-over-here-in-the-periphery-a-decolonial-method-for-romania/.

Roy, Ananya

2019 "Racial Banishment." In Keywords in Radical Geography: Antipode at 50, edited by Antipode Editorial Collective, 227-30. New York: Wiley-Blackwell.

Simone, AbdouMaliq

2018 Improvised Lives: Rhythms of Endurance in an Urban South. Cambridge, UK: Polity. Stengers, Isabelle

2005 “The Cosmopolitical Proposal.” In Making Things Public: Atmospheres of Democracy, edited by Bruno Latour and Peter Weibel, 994-1003. Cambridge, Mass.: MIT Press.

Stevenson, Lisa

2014 Life Beside Itself: Imagining Care in the Canadian Arctic. Los Angeles: University of

Vincze, Enikö California Press.

2017 "The Ideology of Economic Liberalism and the Politics of Housing in Romania." Studia Universitatis Babeș-Bolyai Studia Europaea 62, no. 3: 29-54. http://doi. org/10.24193/subbeuropaea.2017.3.02. 